\title{
Effect of freezing temperature on quality characteristics of dried persimmons
}

\author{
Ji-Young Choi ${ }^{1}$, Hyeon-Jeong Lee ${ }^{1}$, Jeong-Seok Cho ${ }^{1}$, Yeong-Min Lee \\ Luo $\mathrm{Jin}^{1}$, Jin-Ho Woo ${ }^{1}$, Kwang-Deog Moon ${ }^{1,2 *}$ \\ ${ }^{1}$ Department of Food Science and Technology, Kyungpook National University, School of food science and biotechnology, \\ Daegu 41566, Korea \\ ${ }^{2}$ Food and Bio-Industry Research Institute, Kyungpook National University, Daegu 41566, Korea
}

\section{냉동조건이 건시의 저장 중 품질특성에 미치는 영향}

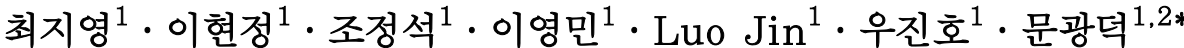 \\ ${ }^{1}$ 경북대학교 식품공학부 식품생물공학전공, ${ }^{2}$ 경북대학교 식품생물산업연구소
}

\begin{abstract}
To evaluate the effect of freezing temperature on quality characteristics of dried persimmons, dried persimmons were frozen at $-50^{\circ} \mathrm{C}$ (quick frozen, QF) and $-20^{\circ} \mathrm{C}$ (slow frozen, SF) for $24 \mathrm{hr}$. Frozen persimmons were then stored at $-20,-10,0$ and $10^{\circ} \mathrm{C}$ for 80 days. Total free sugar content of $\mathrm{SF}$ persimmons was higher than those of $Q F$ in the $+10^{\circ} \mathrm{C}$ and $-20^{\circ} \mathrm{C}$ stored samples. Except for samples stored at $10^{\circ} \mathrm{C}$, the $\mathrm{CIE} \mathrm{L}^{*}$ values for $\mathrm{QF}$ persimmons were higher than those for $\mathrm{SF}$ persimmons. For samples stored at $10^{\circ} \mathrm{C}$ and $0^{\circ} \mathrm{C}$, the $\mathrm{CIE} \mathrm{a}^{*}$ and $b^{*}$ values of SF samples were higher than those for $\mathrm{QF}$ samples. The texture of frozen dried persimmons was investigated to determine springiness, chewiness and hardness. Chewiness and hardness of samples held at $0^{\circ} \mathrm{C}$ were higher in $\mathrm{SF}$ than in QF persimmons. However, when stored at $-10^{\circ} \mathrm{C}$, chewiness and hardness were higher in QF than in SF samples. Springiness results were similar among the QF and SF persimmons held at different storage temperatures. For all storage temperatures, QF persimmons had a high soluble tannin content. All of the sample, the average soluble tannin contents of $Q F$ is $236.09 \mathrm{mg} \%$. On the other hands, those of SF is 226.87 $\mathbf{m g} \%$. The results indicate that freezing rate and holding temperatures have significant effects on dried persimmon texture, soluble tannin level, and free sugar content. Further studies that include sensory evaluations are needed to determine the optimum freezing rate and holding temperature for dried persimmons.
\end{abstract}

Key words : quick freezing, slow freezing, dried persimmons, quality characteristics, storage

\section{서 론}

감(Diospyros kaki)은 동양이 원산지이며, 아열대에서 온 대에 이르기까지 넓은 지역에 분포하며 우리나라 전역에 걸쳐 생산된다(1). 감은 크게 단감과 떫은감으로 구분하며

*Corresponding author. E-mail : kdmoon@knu.ac.kr Phone : 82-53-950-5773, Fax : 82-53-950-6772

Received 9 September 2016; Revised 7 November 2016; Accepted 10 November 2016

Copyright (c) The Korean Society of Food Preservation. All rights reserved.
단감은 주로 생시로 이용되나 떫은감은 연시나 탈삽시, 곶 감 등으로 이용되며(2), 곶감의 경우 고려시대부터 이용해 온 것으로 전해지고 있다(3). 곶감은 과실 건조가공품에 속한 것으로(3), 가을에 일시적으로 다량 출하되는 감과실 의 장기 저장을 위하여 가장 중요한 수단일 뿐만 아니라 풍부한 감미와 탄닌을 지니고 있는 우수한 건조식품으로 건조과정에서 단맛이 증가하고, 비타민 $\mathrm{A}$ 의 함량도 증가한 다(4). 또한 숙혈을 없애고 폐열, 혈토, 구역질, 장풍과 치질 을 다스리는데 쓰인다고 한다(5) 곶감과 관련된 기존 연구 로는 냉풍건조와 천일건조 곶감의 품질특성(6), 상주 전통 곶감 제조과정 중 이화학적 품질특성(7), 곶감, 생감 및 감잎 
추출물의 생리활성효과(8) 등이 있으며, 특히 곶감을 이용 한 가공품 관련 연구로는 곶감주(9), 곶감 추출물 첨가 요구 르트(10), 곶감엿(11), 곶감 추출물 첨가 식빵(12), 곶감추출 물 첨가비율에 따른 곶감젤리(13) 등이 있다. 곶감은 천일 건조, 풍건 등으로 대개 건조되나 건조시간이 1 개월 이상을 요하며 건조기간 중 열기에 따라 곶감의 품질이 크게 영향 을 받게 된다(14). 상품화된 곶감은 대개 $30 \%$ 내외의 수분 함유 상태로 유통되고 있으나(15) 조직이 질기고 딱딱하며 표면의 하얀 분의 과다발생 등으로 인하여 기호도 및 상품 성 저하 등의 문제점이 있다. 상온에서 장기저장 유통하는 과정 중에 곰팡이, 유충의 발생으로 인하여 품질이 변질되 어 상품적 가치가 떨어지기도 한다(16). 따라서 고품질의 건시를 생산하기 위한 연구가 필요한 실정이다.

냉동 공정은 식품 보존에 가장 적절한 방법으로써 영양 성분을 생과에 가장 가깝게 유지할 수 있는 방법이며, 비생 물적, 효소적 활성을 줄여서 과일의 품질저하를 방지하는 효과가 있다(17). 특히 냉동과의 경우 본래의 향미, 색, 조직 감, 영양성분 등이 유지될 수 있을 뿐만 아니라 식품 소재 특유의 신선함을 유지하면서 간편성을 부여하여 매우 다양 하게 사용될 수 있는 장점이 있다(18). 냉동은 수확 후 과채 류의 이화학적 특성을 장기 보존하기 위한 목적으로 널리 사용되고 있으나 얼음 결정 형성에 따른 손상, 조직 균열 등 물리적 변화를 야기한다(19). 국내에서 곶감은 통상적으 로 $-18^{\circ} \mathrm{C}$ 냉동하여 유통되어지고 있지만, 곶감의 냉동기술 연구는 아직 미흡하므로 고품질 건시 유통을 위해서는 적절 한 냉동조건을 찾아 세포내 빙결정 크기와 세포조직의 파괴 를 최소화 하여 조직감 및 영양성분 저하를 억제시킬 수 있는 적절한 냉동기술이 필요하다.

본 연구에서는 냉동 온도 및 저장 온도에 따른 건시의 이화학적 품질 특성을 분석하여 건시의 저장 및 유통에 적합한 최적조건을 모색하고자 한다.

\section{재료 및 방법}

\section{실험재료 및 저장방법}

본 실험에 사용된 시료는 상주 둥시 품종으로 2015년 11 월 경북 상주 곶감 제조 농가로부터 천일건조로 생산된 건시를 $-50^{\circ} \mathrm{C}$ 에 급속 냉동(quick freezing), $-20^{\circ} \mathrm{C}$ 에 완만 냉 동(slow freezing) 시킨 후, 품질이 일정하고 양호한 것을 선별하여 UV 살균된 nylon film $(20 \times 30 \mathrm{~cm})$ 에 3 개씩 포장하 였다. 포장한 건시는 $10^{\circ} \mathrm{C}, 0^{\circ} \mathrm{C}$ 및 $-10^{\circ} \mathrm{C}$ 에 저장하면서 품질 변화를 조사 후 비교하였다. 비교실험을 위한 표준시료는 실제 유통온도인 $-20^{\circ} \mathrm{C}$ 냉동고(CRFD-1762, Samsung, Seoul, Korea)에 보관하였다.

\section{냉동 중 내부온도변화}

건시 90 개를 plastic box $(20 \times 15 \times 42 \mathrm{~cm})$ 에 담은 후, 데이터
로그 멀티신호 기록계(ZR-RX25, OMRON, Kotyo, Japan)를 이용하여 건시 내부온도 변화를 측정하였다. 상자의 하부, 중부, 상부에 있는 각각의 과실 중심에 온도감지 센서를 고정한 후, $-20,-50^{\circ} \mathrm{C}$ 의 냉동고에 넣어 동결시키면서 시료 의 온도변화를 10 초마다 24 시간 동안 측정하여 동결곡선을 구하였다. 냉동속도는 최대 빙결정 형성 구간(-1 - $\left.5^{\circ} \mathrm{C}\right)$ 을 통과하는 시간으로 구하였다.

\section{유리당 함량}

유리당 함량 및 조성은 시료 $5 \mathrm{~g}$ 에 증류수 $45 \mathrm{~mL}$ 를 가하 여 증류수를 채운 $50^{\circ} \mathrm{C}$ 로 설정된 초음파 발생기 $(40 \mathrm{kHz}$, Daihan Scientific Co., Ltd., Seoul, Korea)를 이용하여 3시간 동안 초음파 추출을 하였다. 추출물을 Wattman No. 4 로 여과한 후, $0.45 \mu \mathrm{m}$ membrane filter로 재여과하여 high performance liquid chromatography(HPLC)로 분석을 실시 하였다. 사용된 HPLC(Model Prominence, Shimadzu Co., Tokyo, Japan)는 Sugar-Pak I column $(\varnothing 6.5 \times 300 \mathrm{~mm}$; Waters Co.)을 사용하였고 이동상은 $0.01 \mathrm{M} \mathrm{Ca-EDTA} \mathrm{buffer(50}$ $\mathrm{mg} / 1 \mathrm{~L} \mathrm{~d} . \mathrm{H}_{2} \mathrm{O}$ )를 사용해 $0.5 \mathrm{~mL} / \mathrm{min}$ 유속으로 분석하였다. 표준품으로 glucose(Sigma chemical Co., St. Louis, MO, USA), fructose(Sigma chemical Co.), sucrose(Sigma chemical Co.), mannitol(Sigma chemical Co.), sorbitol(Sigma chemical Co.), raffinose(Sigma chemical Co.), galactose(Sigma chemical Co.)를 일정량씩 혼합하여 증류수에 녹여 표준용 액으로 사용하였다.

\section{색 도}

백색판 $\left(L^{*}=97.79, a^{*}=-0.38, b^{*}=2.05\right)$ 으로 보정한 Colorimeter (CR-400, Minolta, Tokyo, Japan)을 이용하여 L*(lightness), $a^{*}$ (redness), $b^{*}$ (yellowness) 값을 측정하였다.

\section{조직감}

저장 중 건시의 물성은 Rheometer(Compac-100, SunScientific Co., Tokyo, Japan)을 이용하여 측정하였다. 시료를 임의로 선택하여 10 회 반복 측정 후 평균값을 이용 하였으며, 측정 조건으로 adaptor area는 직경 $5 \mathrm{~mm}$, table speed는 $60 \mathrm{~mm} / \mathrm{min}$, 테스트 항목은 hardness, springiness, chewiness로 설정하였다.

\section{가용성 탄닌}

가용성 탄닌 함량은 시료 $5 \mathrm{~g}$ 을 취하여, 마쇄 및 100 배 희석 한 후, Folin-Denis법(20)에 따라 측정하였다. 검액을 Wattman No. 41을 이용해 filter하고, 여과액과 FolinCiocalteu's regent(Sigma chemical Co., St. Louis, MO, USA) 를 1:1로 혼합 후 3 분 정치하였다. 정치 후 $10 \% \mathrm{Na}_{2} \mathrm{CO}_{3}$ 을 넣고 진탕하여, 1 시간 암소 방치 후, UV-Visible spectrophotometer (Evolution 201, Thermo Fisher Scientific 
Inc., Madison, WI, USA)를 이용해 $760 \mathrm{~nm}$ 에 흡광도를 측정 하였다. 이때, tannic acid(Sigma chemical Co.)로 standard curve를 작성하여, 가용성 탄닌 함량을 나타내었다.

\section{통계분석}

건시의 저장온도별 품질 특성 분석 실험결과는 평균과 표준편차로 나타내었으며, SAS program(SAS 9.4, SAS Institute, Cary, NC, USA)의 분산 분석(ANOVA)을 실시하 여 유의성이 있는 경우에 Duncan의 다중범위검정(Duncan's multiple range test)으로 시료간의 유의차를 검증하였다 $(\mathrm{p}<0.05)$.

\section{결과 및 고찰}

\section{동결 온도에 따른 건시의 내부온도변화}

냉동은 식품의 열을 제거하고 식품 속 수분을 고체 상태 로 변화시키는 단위조작으로 냉동속도에 따라 조직특성 및 식품의 품질에 영향을 미치게 된다. $-20,-50^{\circ} \mathrm{C}$ 에서 각각 냉동하면서 시료의 중심의 온도변화를 측정하고 그 결과를 Fig. 1에 나타내었다. 냉동온도가 낮을수록 냉동속도가 증 가하였다. 시료 중심의 온도가 최대 빙결정 형성 구간(-1 $5^{\circ} \mathrm{C}$ )을 통과하는데 $-20^{\circ} \mathrm{C}$ 에서는 34.5 분, $-50^{\circ} \mathrm{C}$ 에서는 14 분 이 소요되었다. 일반적으로 최대 빙결정 형성 구간을 30 분 이내에 통과할 경우 급속냉동이라고 하며, 그 이상의 시간 이 소요될 경우 완만냉동이라고 하는데(21), 건시는 $-50^{\circ} \mathrm{C}$ 에서 냉동한 경우 급속냉동이라 할 수 있고, $-20^{\circ} \mathrm{C}$ 에서는 완만냉동 이라고 할 수 있다. Fig. 1에서 생략되었으나 냉동 이 진행됨에 따라 서서히 온도가 내려가면서 $-20^{\circ} \mathrm{C}$ 에서는 냉동시작 7.2 시간, $-50^{\circ} \mathrm{C}$ 에서는 11 시간 후에 품온이 각각의 냉동고 온도에 도달하였다.

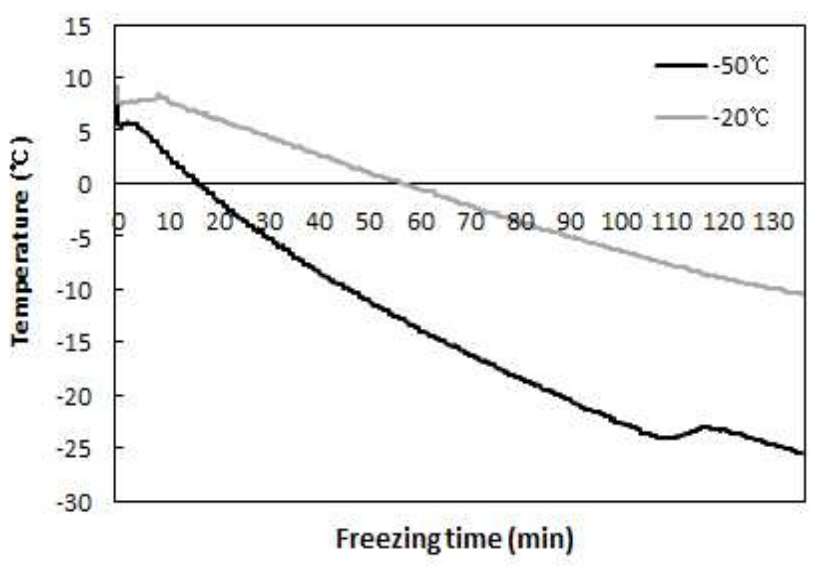

Fig. 1. Change in temperature of dried persimmons during freezing at different temperatures.

\section{유리당}

유리당은 과실류의 단맛에 영향을 주는 것으로 과실즙에 존재하는 고형분 함량보다 더욱 중요하다 할 수 있다(22). 건시에는 대부분 glucose와 fructose로 구성되어 있었으며, sucrose도 검출되었으나 미미한 양이었다. 이는 $\mathrm{Im}$ 과 Lee(23), Moon 등(24)의 연구결과와 같았다. 다음 Table 1에 는 검출된 glucose와 fructose의 합으로 총 유리당 함량을 나타내었다. 총 유리당 함량은 $10^{\circ} \mathrm{C}$ 에서는 전체 저장기간 중 $\mathrm{SF}$ 가 $\mathrm{QF}$ 보다 그 값이 높았다. $-0^{\circ} \mathrm{C}$ 와 $-10^{\circ} \mathrm{C}$ 그리고 $-20^{\circ} \mathrm{C}$ 에서는 모두 저장초기엔 $\mathrm{SF}$ 가 그 함량이 높았으나, 저장기 간이 경과할수록 점차 $\mathrm{QF}$ 가 더 높게 나타났다. 또한 여기서 저장온도가 더 낮을수록 그 경향 변화가 늦게 나타났다. 저장온도와 기간에 따른 경향은 유의적인 차이를 보이지 않았다. $\mathrm{Kim}$ 등(22)의 연구에서는 오디의 저장 전 냉동 온도 가 높을수록 총 유리당 함량이 높다고 보고하였는데 이는 본 연구 결과와 유사했다. 따라서 건시의 유리당 함량 결과

Table 1. Change in total free sugar contents of dried persimmons during storage period

\begin{tabular}{|c|c|c|c|c|c|c|c|}
\hline \multirow{2}{*}{$\begin{array}{c}\text { Temp. } \\
\left({ }^{\circ} \mathrm{C}\right)\end{array}$} & \multirow{2}{*}{ Sample ${ }^{1)}$} & \multicolumn{6}{|c|}{ Storage period (day) } \\
\hline & & 0 & 10 & 20 & 35 & 50 & 80 \\
\hline \multirow{2}{*}{10} & $\mathrm{QF}$ & $29.19 \pm 0.71^{2 \times(\mathrm{B} 3)}$ & $43.83 \pm 2.73^{\mathrm{bBC}}$ & $43.08 \pm 0.23^{\mathrm{bD}}$ & $46.69 \pm 0.82^{\mathrm{aC}}$ & - & - \\
\hline & SF & $47.07 \pm 1.06^{\mathrm{cA}}$ & $47.03 \pm 1.40^{\mathrm{cABC}}$ & $44.53 \pm 1.03^{\mathrm{CD}}$ & $49.58 \pm 0.54^{\mathrm{cBC}}$ & - & - \\
\hline \multirow{2}{*}{0} & $\mathrm{QF}$ & $29.19 \pm 0.71^{\mathrm{dB}}$ & $42.43 \pm 1.71^{\mathrm{cC}}$ & $49.59 \pm 0.85^{\text {abA }}$ & $50.81 \pm 0.52^{\mathrm{aB}}$ & $50.01 \pm 0.88^{\mathrm{abB}}$ & $48.42 \pm 1.11^{\mathrm{bC}}$ \\
\hline & $\mathrm{SF}$ & $47.07 \pm 1.06^{\mathrm{aA}}$ & $46.10 \pm 0.51^{\mathrm{aABC}}$ & $44.67 \pm 2.39^{\mathrm{aCD}^{\mathrm{CD}}}$ & $47.28 \pm 2.73^{\mathrm{aC}}$ & $46.18 \pm 0.13^{\mathrm{aC}}$ & $41.52 \pm 1.39^{6 \mathrm{~B}}$ \\
\hline \multirow{2}{*}{-10} & $\mathrm{QF}$ & $29.19 \pm 0.71^{\mathrm{dB}}$ & $43.89 \pm 2.07^{\mathrm{cBC}}$ & $46.23 \pm 0.60^{\mathrm{CABC}}$ & $47.80 \pm 3.54^{\mathrm{cC}}$ & $53.49 \pm 0.51^{\mathrm{aA}}$ & $51.01 \pm 1.56^{\mathrm{abC}}$ \\
\hline & SF & $47.07 \pm 1.06^{\mathrm{bcA}}$ & $48.77 \pm 0.68^{\mathrm{bcA}}$ & $48.13 \pm 1.03^{\mathrm{bcAB}}$ & $49.96 \pm 0.69^{\mathrm{abBC}}$ & $50.86 \pm 0.05^{\mathrm{abB}}$ & $43.88 \pm 1.36^{\mathrm{cA}}$ \\
\hline \multirow{2}{*}{-20} & $\mathrm{QF}$ & $29.19 \pm 0.71^{\mathrm{dB}}$ & $44.16 \pm 0.36^{\mathrm{cBC}}$ & $45.94 \pm 3.91^{\mathrm{bcBCD}}$ & $47.69 \pm 0.43^{\mathrm{bcBC}}$ & $53.43 \pm 1.13^{\mathrm{aA}}$ & $49.13 \pm 2.57^{\mathrm{boC}}$ \\
\hline & SF & $47.07 \pm 1.06^{\mathrm{bcA}}$ & $47.63 \pm 0.67^{\mathrm{bAB}}$ & $48.62 \pm 1.13^{\mathrm{b} A \mathrm{~B}}$ & $48.75 \pm 3.29^{\mathrm{bA}}$ & $53.69 \pm 0.38^{\mathrm{aA}}$ & $44.08 \pm 2.23^{\mathrm{CAE}}$ \\
\hline
\end{tabular}

${ }^{1)} \mathrm{QF}$, quick freezing; SF, slow freezing.

${ }^{2)}$ Means \pm SD

${ }^{3) a-d}$ Means in the same row and ${ }^{A-D}$ means in the same column followed by different small and capital superscript letters, respectively are significantly different ( $\left.\mathrm{p}<0.05\right)$ by Duncan's multiple range test. 
Table 2. Change in $\mathrm{L}^{*}, \mathrm{a}^{*}$ and $\mathrm{b}^{*}$ values of dried persimmons during storage period

\begin{tabular}{|c|c|c|c|c|c|c|c|c|}
\hline & \multirow{2}{*}{$\begin{array}{l}\text { Temp. } \\
\left({ }^{\circ} \mathrm{C}\right)\end{array}$} & \multirow{2}{*}{ Sample ${ }^{1)}$} & \multicolumn{6}{|c|}{ Storage period (day) } \\
\hline & & & 0 & 10 & 20 & 35 & 50 & 80 \\
\hline \multirow{8}{*}{$\mathrm{L}^{*}$} & \multirow{2}{*}{10} & $\mathrm{QF}$ & $35.24 \pm 1.72^{2 \mathrm{aA} 33)}$ & $29.51 \pm 0.87^{\mathrm{bDE}}$ & $30.82 \pm 1.40^{\mathrm{bE}}$ & $31.79 \pm 3.09^{\mathrm{abD}}$ & - & - \\
\hline & & SF & $35.00 \pm 0.02^{\mathrm{aA}}$ & $27.51 \pm 0.87^{\mathrm{bDE}}$ & $28.18 \pm 2.98^{\mathrm{bF}}$ & $26.78 \pm 2.85^{\mathrm{bE}}$ & - & - \\
\hline & \multirow{2}{*}{0} & QF & $35.24 \pm 1.72^{\mathrm{dA}}$ & $37.75 \pm 1.67^{\mathrm{dB}}$ & $55.53 \pm 0.07^{\mathrm{cA}}$ & $64.72 \pm 0.25^{\mathrm{bA}}$ & $64.34 \pm 2.36^{\mathrm{bA}}$ & $73.35 \pm 1.87^{\mathrm{aA}}$ \\
\hline & & SF & $35.00 \pm 0.02^{\mathrm{eA}}$ & $41.33 \pm 1.81^{\mathrm{dA}}$ & $47.76 \pm 2.10^{\mathrm{cB}}$ & $50.57 \pm 1.87^{\mathrm{cB}}$ & $63.58 \pm 0.50^{\mathrm{aA}}$ & $58.72 \pm 3.78^{\mathrm{bC}}$ \\
\hline & \multirow{2}{*}{-10} & $\mathrm{QF}$ & $35.24 \pm 1.72^{\mathrm{eA}}$ & $29.27 \pm 0.57^{\mathrm{fDE}}$ & $42.07 \pm 0.06^{\mathrm{dC}}$ & $52.34 \pm 0.47^{\mathrm{bB}}$ & $45.89 \pm 1.37^{\mathrm{cC}}$ & $64.43 \pm 1.45^{\mathrm{aB}}$ \\
\hline & & SF & $35.00 \pm 0.02^{\mathrm{eA}}$ & $31.18 \pm 1.87^{\mathrm{ID}}$ & $42.89 \pm 0.61^{\mathrm{dC}}$ & $51.18 \pm 1.27^{\mathrm{bB}}$ & $48.85 \pm 0.05^{\mathrm{cB}}$ & $61.98 \pm 0.32^{\mathrm{aBC}}$ \\
\hline & \multirow{2}{*}{-20} & QF & $35.24 \pm 1.72^{\mathrm{bA}}$ & $35.29 \pm 1.07^{\mathrm{bC}}$ & $35.33 \pm 0.43^{\mathrm{bD}}$ & $35.17 \pm 0.51^{\mathrm{bC}}$ & $35.00 \pm 0.59^{\mathrm{bD}}$ & $38.39 \pm 0.66^{\mathrm{aD}}$ \\
\hline & & SF & $35.00 \pm 0.02^{\mathrm{bA}}$ & $34.79 \pm 0.52^{\mathrm{bC}}$ & $34.58 \pm 1.06^{\mathrm{bD}}$ & $34.64 \pm 1.05^{\mathrm{bCD}}$ & $34.69 \pm 1.05^{\mathrm{bD}}$ & $37.31 \pm 0.03^{\mathrm{bD}}$ \\
\hline \multirow{8}{*}{$a^{*}$} & \multirow{2}{*}{10} & $\mathrm{QF}$ & $11.22 \pm 1.06^{\mathrm{aB}}$ & $3.15 \pm 0.19^{\mathrm{cDE}}$ & $6.57 \pm 0.08^{\mathrm{bD}}$ & $4.10 \pm 0.21^{\mathrm{cBC}}$ & - & - \\
\hline & & SF & $13.76 \pm 0.64^{\mathrm{aA}}$ & $3.83 \pm 0.06^{\mathrm{dBCD}}$ & $7.41 \pm 0.54^{b D}$ & $4.84 \pm 0.27^{\mathrm{CB}}$ & - & - \\
\hline & \multirow{2}{*}{0} & QF & $11.22 \pm 1.06^{\mathrm{aB}}$ & $2.52 \pm 0.14^{\mathrm{cE}}$ & $3.55 \pm 0.24^{6 \mathrm{E}}$ & $1.55 \pm 0.06^{\mathrm{dD}}$ & $1.47 \pm 0.16^{\mathrm{dC}}$ & $0.83 \pm 0.04^{\mathbb{d D}}$ \\
\hline & & $\mathrm{SF}$ & $13.76 \pm 0.64^{\mathrm{aA}}$ & $4.55 \pm 1.39^{\mathrm{BBC}}$ & $6.78 \pm 0.50^{\mathrm{bD}}$ & $3.38 \pm 0.13^{\mathrm{CC}}$ & $1.32 \pm 0.23^{\mathrm{dC}}$ & $2.08 \pm 0.13^{\mathrm{dC}}$ \\
\hline & \multirow{2}{*}{-10} & QF & $11.22 \pm 1.06^{\mathrm{aB}}$ & $3.31 \pm 0.70^{\mathrm{dCDE}}$ & $9.00 \pm 0.12^{\mathrm{bC}}$ & $4.04 \pm 0.34^{\mathrm{cdBC}}$ & $4.72 \pm 0.25^{\mathrm{cB}}$ & $2.17 \pm 0.04^{\mathrm{eC}}$ \\
\hline & & SF & $13.76 \pm 0.64^{\mathrm{aA}}$ & $4.76 \pm 0.38^{\mathrm{CB}}$ & $9.26 \pm 0.85^{\mathrm{bC}}$ & $4.40 \pm 0.49^{\mathrm{CB}}$ & $4.25 \pm 0.12^{\mathrm{cB}}$ & $2.42 \pm 0.18^{\mathrm{dC}}$ \\
\hline & \multirow{2}{*}{-20} & $\mathrm{QF}$ & $11.22 \pm 1.06^{\mathrm{CB}}$ & $13.47 \pm 1.06^{\mathrm{bA}}$ & $15.72 \pm 1.06^{\mathrm{aA}}$ & $11.78 \pm 1.22^{\mathrm{bcA}}$ & $7.83 \pm 1.38^{\mathrm{dA}}$ & $6.63 \pm 0.32^{\mathrm{dB}}$ \\
\hline & & SF & $13.76 \pm 0.64^{\mathrm{aA}}$ & $14.17 \pm 0.04^{\mathrm{aA}}$ & $14.58 \pm 0.57^{\mathrm{aB}}$ & $10.92 \pm 0.12^{\mathrm{bA}}$ & $7.25 \pm 0.32^{\mathrm{cA}}$ & $7.53 \pm 0.82^{\mathrm{cA}}$ \\
\hline \multirow{8}{*}{$b^{*}$} & \multirow{2}{*}{10} & $\mathrm{QF}$ & $26.29 \pm 2.98^{\mathrm{aA}}$ & $7.47 \pm 0.39^{\mathrm{bCD}}$ & $9.31 \pm 0.51^{b D}$ & $9.34 \pm 1.06^{\mathrm{bB}}$ & - & - \\
\hline & & SF & $26.81 \pm 0.30^{\mathrm{aA}}$ & $8.48 \pm 0.53^{\mathrm{CBC}}$ & $10.48 \pm 1.00^{\mathrm{bD}}$ & $10.24 \pm 0.79^{\mathrm{bB}}$ & - & - \\
\hline & \multirow{2}{*}{0} & QF & $26.29 \pm 2.98^{\mathrm{aA}}$ & $6.40 \pm 0.30^{6 \mathrm{D}}$ & $5.08 \pm 0.21^{6 \mathrm{E}}$ & $4.54 \pm 0.18^{b D}$ & $4.43 \pm 0.04^{6 \mathrm{E}}$ & $4.06 \pm 0.17^{\mathrm{bE}}$ \\
\hline & & SF & $26.81 \pm 0.30^{\mathrm{aA}}$ & $8.28 \pm 0.72^{\mathrm{C}}$ & $9.30 \pm 0.60^{\mathrm{bD}}$ & $7.89 \pm 0.06^{\mathrm{C}}$ & $4.95 \pm 0.21^{\mathrm{eC}}$ & $5.80 \pm 0.30^{\mathrm{dD}}$ \\
\hline & \multirow{2}{*}{-10} & QF & $26.29 \pm 2.98^{\mathrm{aA}}$ & $8.17 \pm 0.80^{\mathrm{dC}}$ & $12.91 \pm 0.08^{\mathrm{bC}}$ & $9.77 \pm 0.12^{\mathrm{cdB}}$ & $11.43 \pm 0.34^{\mathrm{bcB}}$ & $7.80 \pm 0.01^{\mathrm{dC}}$ \\
\hline & & SF & $26.81 \pm 0.30^{\mathrm{aA}}$ & $10.03 \pm 0.49^{\mathrm{cB}}$ & $12.46 \pm 0.95^{\mathrm{bC}}$ & $10.09 \pm 0.84^{\mathrm{CB}}$ & $11.08 \pm 0.17^{7^{\mathrm{CD}}}$ & $7.48 \pm 0.44^{\mathrm{dC}}$ \\
\hline & \multirow{2}{*}{-20} & QF & $26.29 \pm 2.98^{\mathrm{aA}}$ & $24.08 \pm 2.08^{\mathrm{abA}}$ & $21.88 \pm 1.18^{\mathrm{bA}}$ & $18.55 \pm 1.19^{\mathrm{cA}}$ & $15.23 \pm 1.20^{\mathrm{dA}}$ & $14.68 \pm 0.65^{\mathrm{dB}}$ \\
\hline & & SF & $26.81 \pm 0.30^{\mathrm{aA}}$ & $23.41 \pm 0.47^{\mathrm{bA}}$ & $20.01 \pm 0.63^{\mathrm{cB}}$ & $15.39 \pm 0.61^{\mathrm{dA}}$ & $16.27 \pm 0.60^{\mathrm{eDE}}$ & $15.87 \pm 0.30^{\mathrm{eA}}$ \\
\hline
\end{tabular}

${ }^{1)} \mathrm{QF}$, quick freezing; SF, slow freezing.

${ }^{2)}$ Means \pm SD.

3)ac Means in a row and ${ }^{A-F}$ means in a column followed by different superscripts are significantly different $(p<0.05)$ by Duncan's multiple range test.

로 보아 냉동 온도가 $-50^{\circ} \mathrm{C}$ 보다 $-20^{\circ} \mathrm{C}$ 일 때 품질 특성이 더 우수할 것으로 보인다.

\section{색 도}

식품의 색도 변화는 소비자에게 있어 구매의 지표로서 중요한데 건시는 산소와의 접촉으로 인한 갈변과 곰팡이 발생, 수분의 증발 등으로 인해 표면의 색이 변하게 되어 기호성을 상실하게 된다(25). 저장기간 중 색도 변화는 Table 2로 나타내었다. $\mathrm{L}^{*}$ 값은 $10^{\circ} \mathrm{C}$ 에서 급속 및 완만 냉동 시료가 모두 10 일 경과 감소하였다가 다시 증가하였으며, $0^{\circ} \mathrm{C}$ 에서는 처리구 모두 저장 기간 동안 값이 크게 증가하는 경향을 보인다. 이는 표면에 발생한 백분의 양이 저장기간 동안 증가하였기 때문일 것으로 보인다. $10^{\circ} \mathrm{C}$ 저장의 경우 10 일이 지나면서 곶감에 백분이 나타나기 시작하였으며 특히 $0^{\circ} \mathrm{C}$ 저장 시에는 실온인 $10^{\circ} \mathrm{C}$ 보다 훨씬 빠르게 백
분이 다량으로 나타났는데, 이는 저온조건에서 백분 발생 이 많았다는 노 등의 보고(26)와 유사하였다. 또한 $\mathrm{QF}$ 에 백분이 더 많이 형성되었으므로 $\mathrm{L}^{*}$ 값 더 높게 나타났다. $-20^{\circ} \mathrm{C}$ 에서는 Fig. 2 에서도 볼 수 있듯이 백분이 발생하지는 않았으며, $\mathrm{QF}$ 의 $\mathrm{L}^{*}$ 값이 저장 80 일 동안 더 높았다. 하지만 이는 SF와 큰 유의적인 차이가 나타나지는 않았다. Redness 인 $\mathrm{a}^{*}$ 값은 저장 10 일차에 $-20^{\circ} \mathrm{C}$ 를 제외하고 모든 저장온도 에서 값이 급격하게 감소하였다. 특히 $0^{\circ} \mathrm{C}$ 에서 매우 낮은 값까지 감소하는 것을 확인할 수 있었다. 이 역시 $0^{\circ} \mathrm{C}$ 에서 백분이 다량 발생하여 붉은 정도가 낮아졌기 때문인 것으로 보인다. $\mathrm{a}^{*}$ 과 $\mathrm{b}^{*}$ 값은 모두 $10^{\circ} \mathrm{C}$ 와 $0^{\circ} \mathrm{C}$ 에서 $\mathrm{SF}$ 가 더 높은 경향이 있었으며 다른 온도에서는 경향을 보이지 않았다. 따라서 $\mathrm{L}^{*}$ 값이 높은 것은 백분으로 인해 표면 밝기가 밝게 측정된 것이며, 백분은 소비자의 기호도를 감소시키는 요 인이 된다. 또한 $\mathrm{a}^{*}$ 과 $\mathrm{b}^{*}$ 값이 상대적으로 높은 $\mathrm{SF}$ 는 건시 


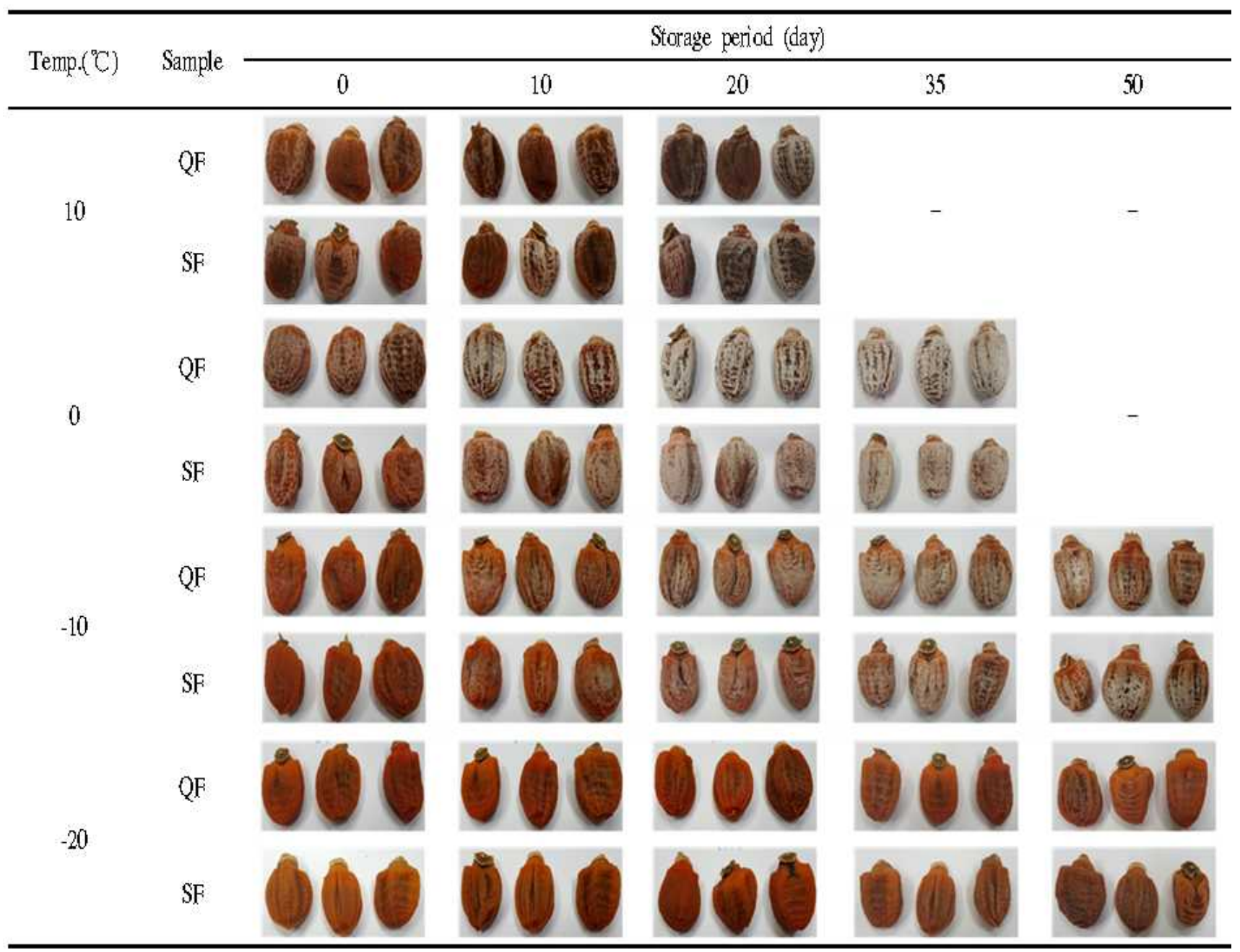

Fig. 2. Captured images of dried persimmons during storage after freezing at different temperatures.

QF, quick freezing; SF, slow freezing.

고유의 색택을 $\mathrm{QF}$ 보다 높게 나타내고 있으므로 Fig. 2와 색도 변화 결과를 비교하여 보았을 때, $\mathrm{SF}$ 가 더 좋은 색도를 같은 것으로 보인다.

\section{조직감}

본 연구에서 측정한 물성 항목은 탄력성(springiness), 씹 힘성(chewiness) 및 경도(hardness)로, 냉동온도 및 저장온 도에 따른 rheometer 측정 결과는 Table 3에 나타내었다. 탄력성은 저장기간, 저장온도에 따른 유의적 차이를 보이 지 않았다. $-20^{\circ} \mathrm{C}$ 에서는 $\mathrm{SF}$ 가 $\mathrm{QF}$ 보다 높은 탄력성을 가졌 다. 건시의 씹힘성은 전체 저장 기간 동안 $0^{\circ} \mathrm{C}$ 와 $-20^{\circ} \mathrm{C}$ 에서 는 SF가 더 높았으며, 다른 온도에서는 유의적 경향이 나타 나지 않았다. 경도는 건조제품인 건시의 품질을 결정하는 물리적 인자 중 가장 중요한 요소라고 할 수 있다. 경도는 $10^{\circ} \mathrm{C}$ 에서는 $\mathrm{QF}, \mathrm{SF}$ 모두 값이 증가하다가 감소하는 모습을 보이며 SF가 경화가 더 빨리 진행되었다. 이는 저장 중 건시 내부 수분이 외부로 방출되면서 경화가 진행되었다가
품질이 저하되면서 과육이 짓무르기 때문인 것으로 보인 다. 또한 저장 $80^{\circ}$ 일차에 $0^{\circ} \mathrm{C},-20^{\circ} \mathrm{C}$ 의 $\mathrm{SF}, 10^{\circ} \mathrm{C}$ 의 $\mathrm{QF}$ 의 경도 값이 $8,000 \mathrm{~g} / \mathrm{cm}^{2}$ 이상으로 급증하는 모습을 볼 수 있다. 특히 $0^{\circ} \mathrm{C},-20^{\circ} \mathrm{C}$ 의 $\mathrm{SF}$ 는 저장기간 전반적으로 $\mathrm{QF}$ 보다 높게 나타났고 이는 씹힘성의 결과와 유사한 경향이었다. 반면 에 이를 제외한 나머지 구에서는 $\mathrm{SF}$ 와 $\mathrm{QF}$ 가 유의적 차이 없이 저장 80 일 동안 비슷한 값을 유지하였다. 본 연구의 조직감 실험 결과로 $0^{\circ} \mathrm{C}$ 와 $20^{\circ} \mathrm{C}$ 에서는 전체 저장 기간 동안 $\mathrm{SF}$ 에서 조직 경화 현상이 더 심하다고 판단되며, $\mathrm{SF}$ 는 $10^{\circ} \mathrm{C}$ 에서 10 일차, $0^{\circ} \mathrm{C},-20^{\circ} \mathrm{C}$ 에서 50 일차에 경화가 가장 많이 일어났다. 저장 유통 시 생기는 조직 품질 저하를 막기 위해 냉동 온도 및 저장 온도를 조절하여 품질유지에 효과를 줄 수 있을 것으로 예상된다.

\section{가용성 탄닌}

Table 4는 저장 중 가용성 탄닌 함량 변화를 나타낸 것이 다. 가용성 탄닌 물질은 polyphenolic compound의 일종으로 
Table 3. Change in texture of dried persimmons during storage period

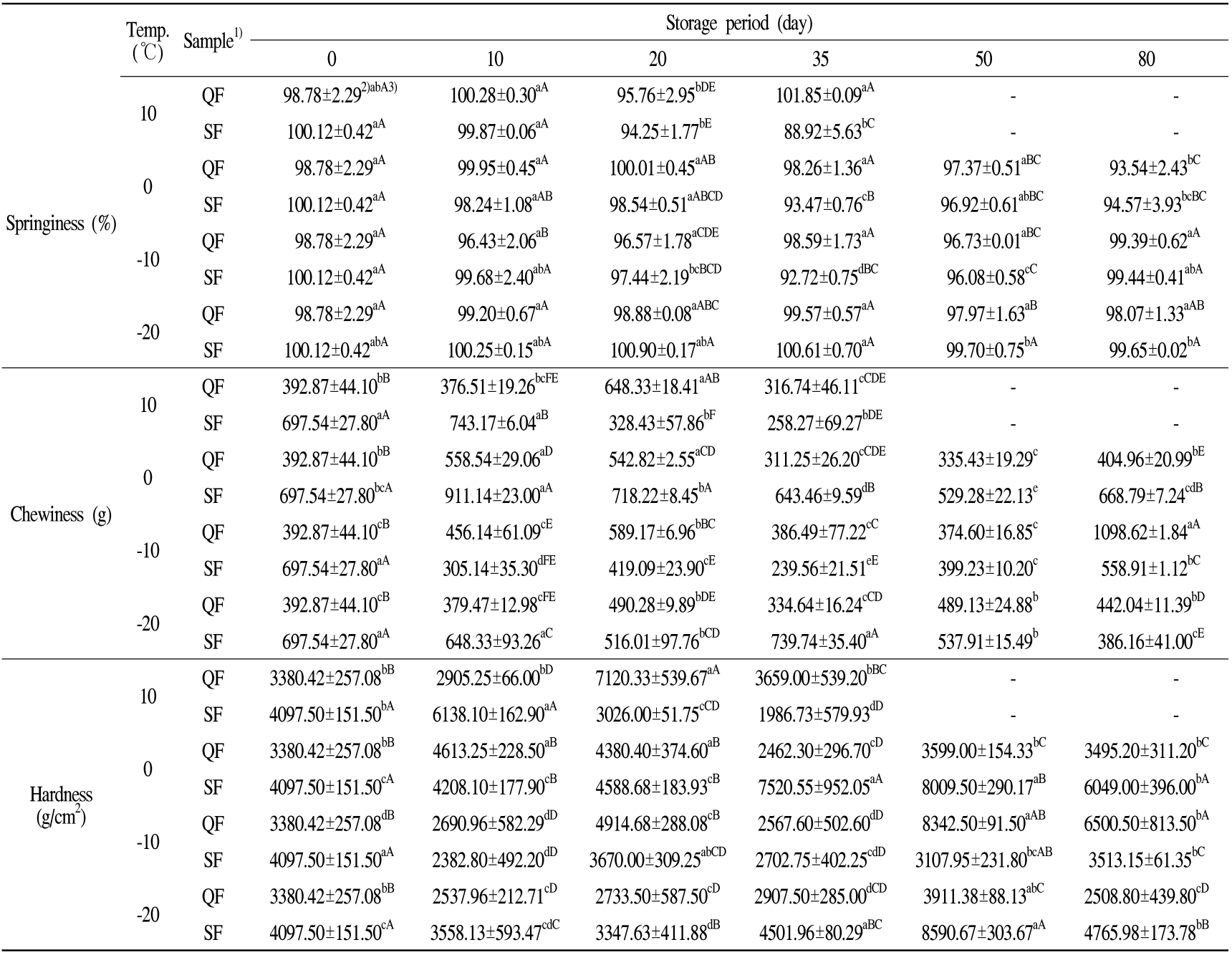

${ }^{1)} \mathrm{QF}$, quick freezing; SF, slow freezing.

${ }^{2)}$ Means \pm SD .

${ }^{3) a-e}$ Means in a row and ${ }^{A-F}$ means in a column followed by different superscripts are significantly different $(p<0.05)$ by Duncan's multiple range test.

Table 4. Change in soluble tannin of dried persimmons during storage period

(unit: $\mathrm{mg} \%$ )

\begin{tabular}{|c|c|c|c|c|c|c|c|}
\hline \multirow{2}{*}{ Temp. $\left({ }^{\circ} \mathrm{C}\right)$} & \multirow{2}{*}{ Sample $^{1)}$} & \multicolumn{6}{|c|}{ Storage period (day) } \\
\hline & & 0 & 10 & 20 & 35 & 50 & 80 \\
\hline \multirow{2}{*}{10} & $\mathrm{QF}$ & $227.45 \pm 3.04^{2) \mathrm{cA} 3)}$ & $245.40 \pm 4.26^{\mathrm{bC}}$ & $275.33 \pm 8.83^{\mathrm{aBC}}$ & $205.23 \pm 3.96^{\mathrm{dDE}}$ & - & - \\
\hline & SF & $225.62 \pm 3.65^{\mathrm{cA}}$ & $237.95 \pm 4.11^{\mathrm{bD}}$ & $271.17 \pm 9.50^{a \mathrm{C}}$ & $203.26 \pm 2.59^{\mathrm{dDE}}$ & - & - \\
\hline \multirow{2}{*}{0} & $\mathrm{QF}$ & $227.45 \pm 3.04^{\mathrm{bA}}$ & $232.01 \pm 3.96^{6 \mathrm{E}}$ & $294.25 \pm 1.98^{\mathrm{aAB}}$ & $225.22 \pm 4.13^{\mathrm{bB}}$ & $210.10 \pm 5.17^{\mathrm{CD}}$ & $187.48 \pm 17.20^{\mathrm{dB}}$ \\
\hline & SF & $225.62 \pm 3.65^{\mathrm{cA}}$ & $291.21 \pm 1.07^{\mathrm{aA}}$ & $263.36 \pm 20.44^{\mathrm{bCD}}$ & $201.89 \pm 1.83^{\mathrm{dE}}$ & $202.80 \pm 2.13^{\mathrm{dC}}$ & $185.15 \pm 1.22^{\mathrm{eB}}$ \\
\hline \multirow{2}{*}{-10} & $\mathrm{QF}$ & $227.45 \pm 3.04^{\mathrm{bA}}$ & $247.69 \pm 4.11^{\mathrm{bcC}}$ & $298.66 \pm 1.83^{\mathrm{aAB}}$ & $208.13 \pm 0.15^{\mathrm{cDE}}$ & $223.95 \pm 2.28^{\mathrm{bA}}$ & $201.08 \pm 8.59^{\mathrm{dAB}}$ \\
\hline & SF & $225.62 \pm 3.65^{\mathrm{cA}}$ & $213.45 \pm 1.22^{\mathrm{cF}}$ & $266.10 \pm 19.17^{\mathrm{abCD}}$ & $201.89 \pm 2.43^{\mathrm{dE}}$ & $213.15 \pm 5.17^{\mathrm{cdB}}$ & $199.55 \pm 11.26^{\mathrm{dAB}}$ \\
\hline \multirow{2}{*}{-20} & $\mathrm{QF}$ & $227.45 \pm 3.04^{\mathrm{bcA}}$ & $245.86 \pm 1.37^{\mathrm{abC}}$ & $282.43 \pm 8.73^{\mathrm{aABC}}$ & $234.30 \pm 3.50^{\mathrm{abA}}$ & $214.36 \pm 4.26^{\mathrm{bcB}}$ & $252.61 \pm 22^{\mathrm{abAB}}$ \\
\hline & SF & $225.62 \pm 3.65^{\mathrm{bA}}$ & $254.08 \pm 0.76^{\mathrm{AB}}$ & $246.11 \pm 0.35^{\mathrm{aD}}$ & $220.30 \pm 0.76^{6 \mathrm{E}}$ & $221.67 \pm 0.91^{\mathrm{bA}}$ & $195.70 \pm 14.11^{\mathrm{cB}}$ \\
\hline
\end{tabular}

${ }^{1)} \mathrm{QF}$, quick freezing; SF, slow freezing.

${ }^{2)}$ Means \pm SD.

${ }^{3)-\mathrm{a}} \mathrm{Meeans}$ in a row and ${ }^{\mathrm{A} \cdot \mathrm{F}}$ means in a column followed by different superscripts are significantly different $(\mathrm{p}<0.05)$ by Duncan's multiple range test. 
수용성이며 그 수용액은 혀의 점막단백질을 응고시켜 강한 삽미를 느끼게 하여(27) 식품제조 및 가공 시 많은 장애를 일으킨다 (28) $10^{\circ} \mathrm{C}, 0^{\circ} \mathrm{C},-10^{\circ} \mathrm{C}$ 에서는 저장기간 동안 $\mathrm{QF}$ 의 가용성 탄닌 함량이 $\mathrm{SF}$ 보다 높았다. $-20^{\circ} \mathrm{C}$ 에서는 냉동조건 에 따른 유의적 차이가 없음을 확인하였다. 모든 처리구에 서 저장온도별 경향은 나타나지 않았다. 따라서 전반적인 결과로 미루어볼 때 $\mathrm{QF}$ 가 가용성 탄닌 함량이 높은 것을 알 수있었으므로 가용성 탄닌의 특성으로 미루어 보아 $\mathrm{SF}$ 의 품질특성이 더 우수할 것으로 판단된다.

\section{요 약}

본 연구는 건시의 냉동 온도를 달리하여, 저장기간 중 품질특성변화를 분석하고 비교하였다. 연구 결과, 유리당 함량은 $10^{\circ} \mathrm{C},-20^{\circ} \mathrm{C}$ 에서는 저장기간 전체에서 $\mathrm{SF}$ 가 더 많았 다. 건시의 $\mathrm{L}^{*}$ 값은 $10^{\circ} \mathrm{C}$ 에서는 표면 갈변에 의해 감소하며, $0^{\circ} \mathrm{C},-10^{\circ} \mathrm{C}$ 에서는 백분발생에 의해 그 값이 증가했다. $\mathrm{QF}$, $\mathrm{SF}$ 모두 $0^{\circ} \mathrm{C}$ 에서 백분이 가장 많이 발생하여 $\mathrm{L}^{*}$ 값이 저장온 도 중 가장 높았으며, $\mathrm{QF}$ 에 백분이 더 많이 형성되어 그 값이 더 높았다. a 값은 모든 저장온도에서 감소하는 경향 을 보였으며, $10^{\circ} \mathrm{C}, 0^{\circ} \mathrm{C}$ 에서 $\mathrm{SF}$ 가 더 높았다. 조직감은 탄력 성, 씹힘성, 경도를 조사하였으며, $0^{\circ} \mathrm{C}$ 와 $-20^{\circ} \mathrm{C}$ 를 비롯한 전반적인 건시의 경도는 전체 저장 기간 동안 $\mathrm{SF}$ 에서 조직 경화 현상이 더 심하다고 판단하였다. 가용성 탄닌 함량은 $-20^{\circ} \mathrm{C}$ 를 제외하고 모든 저장온도에서 $\mathrm{QF}$ 가 더 높은 경향이 나타났다. 본 연구의 결론으로 냉동조건에 따른 경향성 있 는 결과가 도출된 것으로 미루어 보아, 건시의 저장 전 냉동 온도는 저장 중 품질 변화에 영향을 줄 것으로 사료되며, 유리당, 색도, 가용성 탄닌 측면에서 $\mathrm{SF}$, 즉 완만냉동 시료 가 저장 중 품질특성이 더 좋을 것으로 보이지만 조직경화 면에서는 $\mathrm{SF}$ 의 품질이 좋지 않다고 판단된다. 본 연구를 바탕으로 냉동 온도에 따른 관능적 평가와 미생물생육정도 에 대한 추가적인 연구가 필요할 것으로 보인다.

\section{감사의 글}

본 논문은 농촌진흥청 연구사업(PJ011664022016)의 지 원에 의해 수행된 연구결과로 이에 감사드립니다.

\section{References}

1. Cho KM, Lee JB, Kahng GG, Seo WT (2006) A study on the making of sweet persimmon (Diospyros kaki $\mathrm{T}$ ) wine. Korean J Food Sci Technol, 38, 785-792
2. Lee MH, Lee SH, Park SD, Choi BS (1995) The effect of package material and moisture content on storage of dried persimmons at room temperature. Korean J Food Preserv, 2, 285-291

3. Kim JK, Kang WW, Oh SL, Kim JH, Han JH, Moon HK, Choi JU (2004) Comparison of quality characteristics on traditional dried persimmons from various regions. J Korean Soc Food Nutr, 33, 140-145

4. Hong EY, Kim YC, Rhee CH, Kang WW, Choi JU, Chung SK (2001) Changes of microflora in processing and preservation of dried persimmon. Korean J Food Preserv, 8, 374-378

5. Akira S, Hisashi H, Takashi T (1975) Studies on the removability of astringency in Japanese persimmon fruits. J Jpn Soc Hortic Sci, 44, 265-272

6. Lee YR, Chung HS, Moon KD (2011) Change in the polyphenol content of Cheongdobansi persimmon fruit during development. Korean J Food Preserv, 18, 13-17

7. Kang WW, Kim JK, Oh SL, Kim JH, Han JH, Yang JM, Choi JU (2004) Physicochemical characteristics of Sangju traditional dried persimmons during drying process. J Korean Soc Food Sci Nutr, 33, 386-391

8. Hong JH, Kim HJ, Choi YH, Lee IS (2008) Physiological activities of dried persimmon, fresh persimmon and persimmon leaves. J Korean Soc Food Sci Nutr, 37, 957-964

9. Woo KL, Lee SH (1994) A study on wine-making with dried persimmon produced in Korea. Korean J Food Sci Technol, 26, 204-212

10. Ko SH, Kim SI, Han YS (2008) The quality characteristics of yogurt add supplemented with low grade dried persimmon extracts. Korean J Food Cook Sci 24, 735-741

11. Kim JH, Kang WW, Kim JK (2005) Quality evaluation of Yut (Korean traditional candy) prepared from low quality dried persimmon. Korean J Food Preserv, 12, 135-140

12. Moon HK, Han JH, Kim JH, Kim GY, Kang WW, Kim JK (2004) Quality characteristics of bread with dried persimmons hot-water extracts. J Korean Soc Food Sci Nutr, 33, 723-729

13. Kim JH, Kim JK (2005) Quality of persimmon jelly by various ratio of dried persimmon extract. J Korean Soc Food Sci Nutr, 34, 1091-1097

14. Park HW, Kim SH, Lee SA, Park JD (2012) Quality change of chill-stored dried persimmons affected by cinnamon extract pre-treatment and packaging condition. 
Korean J Packaging Sci Technol, 18, 9-14

15. Kim HY, Chuag HJ (1995) Changes of physicochemical properties during the preparation of persimmon pickles and its optimal preparation conditions. Korean J Food Sci Technol, 27, 697-702

16. Kang BH, Jo MY, Hur SS, Shin KS, Lee DS, Lee SH, Lee JM (2012) Isolation and identification of contaminated organisms on dried persimmon. Korean J Food Preserv, 19, 939-945

17. Chassagne-Berces S, Fonseca F, Citeau M, Marin M (2010) Freezing protocol effect on quality properties of fruit tissue according to the fruit, the variety and the stage of maturity. LWT-Food Sci Technol, 43, 1441-1449

18. Tressler DK, Evers CF (1946) The freezing preservation of foods. 2th ed, Avi Publishing Co, New York, NY, USA, p 244-247

19. Taylor, Francis group (2005) Handbook of frozen food processing and packaging. CRC Press, Boca Raton, FL, USA, p 391-396

20. Schanderl SH (1970) Tannins and related phenolics. In: Methods in Food analysis, Joslyn MA (Editor), Academic Press, New York, NY, USA, p 701-711

21. Koh SM, Rhim JW, Kim JM (2011) Effect of freezing temperature on the rehydration properties of freeze-dried fice porridge. Korean J Food Sci Technol, 43, 509-512
22. Kim JE, Jo HJ, Yu MJ, Song KB, Kim HY, Park JT (2015) Effects of freezing temperature on quality of mulberry. Korean J Food Sci Technol, 47, 267-271

23. Im JS, Lee MH (2007) Physicochemical compositions of raw and dried Wolha persimmons. Korean J Food Preserv, 14, 611-616

24. Moon KD, Kim JK, Kim JH, Oh SL (1995) Studies on valuable components and processing of persimmon flesh and peel. J Korean Soc Food Cult, 10, 321-326

25. Park HW, Cha HS, Kim SH, Park HR, Lee SA, Kim YH (2006) Effects of grapefruit seed extract pretreatment and packaging material on quality of dried persimmons. Korean J Food Preserv, 13, 168-173

26. No YK, SH Jang, TS Park and SH Park (1997) Processing of the astringent persimmon, using established technology system testing, quality improvement of dried persimmons. Report of agricultural experiment study, vol.2 Regionspecific crops sector, 1201-1211

27. Seo JH, Jeong YJ, Kim KS (2000) Physiological characteristics of tannin isolated from astringent persimmon fruits. Korean J Food Sci Technol, 32, 212-217

28. Ravichandran R, Parthiban R (1998) Changes in enzyme activities (polyphenol oxidase and phenylalanine ammonia lyase) with type of tea leaf and during black tea manufacture and the effect of enzyme supplementation of dhool on black tea quality. Food Chem, 62, 277-281 